\title{
Does Economic Integration Affect Inequality in Developing Countries? Evidence from a Global Sample
}

\author{
By Le Thanh Tung ${ }^{1 *}$, Pham Nang Thang ${ }^{2}$, Lam Tu Uyen ${ }^{3}$
}

\begin{abstract}
Economic integration plays an important role in promoting economic growth. However, it can also increase inequality, although the relationship between economic integration and inequality is still unclear. Our paper aims to study the impact of economic integration on income inequality with a global sample regarding 59 developing countries collected from 1996-2016. Besides, we divide the overall sample into three smaller examples including developing countries in Asia, Africa, and LatinAmerica. Unlike previous studies, our research results confirm that economic integration has a multidimensional impact on inequality in countries. In detail, trade openness can help to reduce inequality, however, foreign direct investment increases inequality during the study period. The Kuznets' inverted-U curve among income and inequality is confirmed in the cases including the overall sample, Asia and Africa, excluding for the Latin-America. Finally, technology development and remittances are found to play a negative impact on inequality, while inflation leads to an increase in inequality level in developing countries.
\end{abstract}

Keywords: economic integration, inequality, trade openness, FDI, Ku₹nets, developing country

\section{Introduction}

Economic integration paves the way for trade liberalization, promoting competitiveness, enhance freedom level in the business environment, support technology transfer (Bergh \& Nilsson, 2010; Franco \& Gerussi, 2013). Economic integration also facilitates for countries in attracting foreign direct investment (Alderson \& Nielser, 2002). Thus, foreign direct investment flows are external resources that play an important role in promoting economic growth (eg., Nguyen, Le, \& Pham, 2017; Tung, 2018a), supporting private investment (eg., Tung, 2019; Tung \& Thang, 2020), spillover new technologies and disseminating management skills (Markusen \& Venables, 1999; Park \& Park, 2009). Besides, through the increasing competitive level, economic integration creates opportunities for businesses to effectively use their available resources including physical capital, labour force, technological knowledge. Economic integration also leads to lower production costs, fewer barriers to trade, and faster expand business ideas (Hoekman et al., 2002). However, economic agents with different conditions of capital, management level, and labour force react differently to the fluctuations brought by economic integration. Besides, the increase in economic integration also helps raise the international trade of countries. Consequently, the trade balance of a country is one of the indicators for measuring the level of the economic integration of this country

1 Associate Professor (Ph.D.), Faculty of Economics and Public Management, Ho Chi Minh City Open University, Ho Chi Minh City, Vietnam.*Corresponding Author: tung.lt@ou.edu.vn

${ }^{2}$ Assistant Researcher, Master of Economics, Graduate School, Ho Chi Minh City Open University, Ho Chi Minh City, Vietnam

${ }^{3}$ Assistant Researcher, Master of Economics, Binh Thuan Community College, Vietnam 
(Dollar \& Kraay, 2004; Franco \& Gerussi, 2013; Ezcurra \& Rodríguez-Pose, 2014). On the other hand, economic integration also is received some concerns about some negative impact of it on social indicators such as increasing inequality (Ametoglo \& Ping, 2016). Economic integration creates greater opportunities for countries to participate in international supply chains through the trade of goods and services (Iyoha, 2005). However, the technology level and the efficiency of using the inputs are different, therefore, labour productivity and income received are also different. In addition, the level of participation in the international value chain is different, so the benefits received from economic integration also vary. As a result, economic integration can lead to an increase in the inequality level (Goldberg \& Pavcnik, 2007; Nascia \& Pianta, 2009). Besides, economic integration can make a disparity of living standards among people and raise inequality (Daumal, 2013). There are individuals who can not eligible for catchingup with the general development trend, they can be dismissed or left out of this process (Bergh \& Nilsson, 2010). Thus, economic integration has a certain impact on the fluctuation of income inequality in countries as well as regions.

Recently, there have been many research results related to the relationship between economic integration and inequality in developing countries, however, the results have not been consistent. There are three different directions of the economic integrationinequality nexus that are found in the previous studies. Firstly, there are some evidences that economic integration increases inequality (Alderson \& Nielser, 2002; Goldberg \& Pavcnik, 2007; Nascia \& Pianta, 2009; Wu \& Hsu, 2012; Daumal, 2013; Mihaylova, 2015). Secondly, some studies show that economic integration leads to reduce inequality (eg., Zhou et al., 2011; Daumal, 2013; Jiang, 2016; Inekwe et al., 2018). Thirdly, some other results suggest that economic integration is not related to inequality (Tian et al., 2008; Franco \& Gerussi, 2013; Beak \& Shi, 2015; Wong, 2016). Furthermore, most of the previous research results only focus on a certain country such as China (eg., Wei \& Wu, 2001; Tian et al., 2008; ) or Vietnam (eg., Le \& Booth, 2014) or only related to a specific region such as Latin America.

Our paper aims to fill the research gap on the impact of economic integration on inequality in developing countries with a global research sample. Our research results have three new contributions to the literature of economic integration - inequality nexus. Firstly, our study may be the first evidence of the impact of economic integration on inequality focused on a sample regarding only the developing countries. Secondly, unlike previous studies that considered economic integration is only denoted by trade openness variable, in this study, we go further with the simultaneous applying of two variables including trade openness and FDI to represent the economic integration of developing countries. Third, our research is deeper than previous studies because we split the database into various samples such as full panel, Asia, Africa, the Latin-America. Following to this estimated strategy, the quantitative results among regions will be compared and discuss to have new findings. Besides, our research results will provide an overview of the topic of analysis and comparisons that discussing differences between regions. Generally, our results are very useful for policymakers in promoting economic integration but still reducing income inequality in economies.

This paper is structured into five sections. Section 2 presents an overview of the theoretical basis. Section 3 shows the methodology, econometric model and data source. 
Section 4 has quantitative results and discussions. Finally, section 5 is conclusions and some policy implications.

\section{Literature Review}

Economic integration is a necessary condition for countries to promote economic growth in the context of globalization. Therefore, economic integration plays a critical role in the development strategy of many countries worldwide. On the other hand, income inequality has also become a highlighted problem in recent global social issues. Some reliable statistics show that there is an increase in posting inequality over the world. In recent years, there have been some research results regarding the relationship between economic integration and inequality in some developing countries. However, these results are not consistent or even contradictory inverse to each other. Based on our review of the literature, the previous results are simply divided into three main groups.

In the first group, there are some research results show that economic integration can reduce income inequality in the host countries. Daumal (2013) investigated the effect of trade openness on regional inequality in the case of India and Brazil. Where the Gini index measured income inequality and trade openness was calculated by the sum of exports and imports divided by GDP. The empirical result showed that open trade had a positive impact on income inequality only in India, while open trade had a negative impact on income inequality in Brazil. Besides, Zhou et al. (2011) conducted a study on the effects of globalization on the distribution of income inequality with a sample regarding 60 countries. The result showed that globalization had an inverse relationship to inequality. In the study done by Inekwe et al. (2018), there was a new approach to financial integration and market income inequality with a composite sample of 39 countries in 1989-2014. The author used the Gini market variables and the Gini net to measure market income inequality and net income inequality. While financial integration was measured by loan contract indices, lending countries, borrowing countries, lending centers, and agricultural land. The research result showed that financial integration reduced market inequality but increased net inequality. Meniago and Asongu (2018) studied the relationship between financial development and income inequality in 40 African countries in 1996-2004. The authors concluded that financial development had a negative effect on income inequality in this region.

In the second group, some empirical research results that show economic integration has a positive effect on inequality. Alderson and Nielser (2002) conducted a study on globalization and trends in income inequality in 16 OECD countries between 1967 and 1992. Globalization was measured by foreign direct investment, foreign trade, openness, and migration, while inequality was measured by the Gini index. Their result concluded that globalization made inequality in 16 OECD countries increased. Besides, Wu and Hsu (2012) done a study in 54 countries between 1980 and 2005. They used some variables including Gini (denote inequality), FDI, trade (denote integration). The research showed that FDI could harm the income distribution of low-capacity recipient countries, however, it had little effect on inequality in countries with better absorption capacity. Furthermore, Ametoglo and Ping (2016) investigated regional economic integration and income inequality in the case of the Andean Community consisted of 4 countries Bolivia, 
Columbia, Ecuador, and Peru in the period of 2000-2013. The authors pointed out that trade in the region was positively related to income inequality, while FDI had an inverse relationship with income inequality.

In the third group, some research results suggested economic integration did not affect inequality. Tian et al. (2008) studied the impact of economic integration on income inequality in China in 1979-2006. The study implied that economic integration did not affect income inequality in China. On the other hand, Franco \& Gerussi (2013) investigated whether trade and foreign direct investment affect income distribution in the 18 countries in the period of 1990-2006. However, the authors concluded that FDI and trade had a negligible impact on income inequality. Beak and Shi (2015) studied the impact of economic globalization on income inequality in developed economies and emerging economies. The authors used the trade intensity and financial integration as the presentation of globalization. However, the results indicated that globalization did not relate to income inequality. Wong (2016) studied the relationship between globalization, spending, and income inequality in the Asia-Pacific region. The quantitative result presented that globalization did not affect income inequality in this region.

Overview from the literature, it is can be seen that there are some studies regarding the economic integration-inequality nexus, however, the previous results did not clearly show this relationship. To the best of our knowledge, our paper is the first to consider this issue with a global sample of developing countries.

\section{Methodology and Data}

In order to investigate the effect of economic integration on inequality in developing countries, we will conduct an econometric equation that has a dependent variable (inequality) and some independent variables (FDI, trade openness, GDP per capita, technology, government expenditure, inflation, remittance, and corruption). According to the theory of Kuznets (1955), our paper combines both linear and nonlinear models to test the impact of economic integration on income inequality. The research model is presented as the below equation.

Inequality ${ }_{\mathrm{i}, \mathrm{t}}=\beta_{1}+\beta_{2}$ LnGDPcapita $_{\mathrm{i}, \mathrm{t}}+\beta_{3}$ LnGDPcapita $_{\mathrm{i}, \mathrm{t}}+\beta_{4} \mathrm{FDI}_{\mathrm{i}, \mathrm{t}}+\beta_{5}$ Openness $_{\mathrm{i}, \mathrm{t}}+$

$+\beta_{6}$ Technology $_{\mathrm{i}, \mathrm{t}}+\beta_{7}$ Remittances $_{\mathrm{i}, \mathrm{t}}+\beta_{8}$ GExpenditure $_{\mathrm{it}}+$

$+\beta_{9}$ Inflation $_{i, t}+\beta_{10}$ Corruption $_{i, t}+\varepsilon_{i, t}(1)$

Where Inequality is an inequality variable that is measured by the Gini index. Openness is the Trade openness measured by the sum of export plus import and dividing GDP (unit is \% of GDP). FDI is the foreign direct investment inflow (unit is \% GDP). GDPcapita is GDP per capita (Unit is USD), in our equation, we use the natural logarithm of GDPcapita. Technology is the percentage of internet users in the total population (unit is \%). Remittances is the ratio of remittance flows in GDP (unit is \% GDP). Inflation is represented by the change of the Customer Price Index (unit is \%). GExpenditure is the ratio of government expenditure in GDP (unit is \% GDP). Corruption is the level of Corruption control (unit is \%).

To investigate the effect of economic integration on income inequality, we employ the OLS technique with both the fixed effects model (FEM) and the Random effects model (REM). To choose which is a better one, we will use the Hausman test to make a 
decision. In detail, when the null hypothesis is rejected (by a P-value is smaller 0.05), the REM is biased and the FEM will be chosen, and otherwise.

Our statistical sample has collected from 59 developing countries in 1996-2016. List of countries used in our study including Armenia, Bangladesh, Cambodia, China, Georgia, India, Indonesia, Kyrgyz Republic, Mongolia, Nepal, Lao, Pakistan, Philippines, Sri Lanka, Myanma, Syrian Arab Republic, Tajikistan, Timor-Leste, Thailand, Uzbekistan, Vietnam, Yemen (Asian developing countries), Algeria, Belize, Botswana, Burundi, Côte d'Ivoire, Cameroon, Cape Verde, Djibouti, Ghana, Kenya, Morocco, Mozambique, Malawi, Rwanda, Senegal, Swaziland, Tanzania, Zambia, Zimbabwe, Lesotho, Niger, Burkina Faso (African developing countries), Brazil, Bolivia, Colombia, Costa Rica, Dominican Republic, Venezuela, Mexico, Guatemala, Guyana, Honduras, Nicaragua, Paraguay, El Salvador, Jamaica, Ecuador (Latin-American developing countries). The data source is directly downloaded from the World Bank Development Indicators database (World Bank, 2019). We have a descriptive statistics of the variables in Table 1.

Table 1: The descriptive statistics of the variables

\begin{tabular}{|l|c|c|c|c|c|}
\hline Variables & $\begin{array}{c}\text { Observation } \\
\text { number }\end{array}$ & Mean & $\begin{array}{c}\text { Standard } \\
\text { deviation }\end{array}$ & $\begin{array}{c}\text { Minimum } \\
\text { value }\end{array}$ & $\begin{array}{c}\text { Maximum } \\
\text { value }\end{array}$ \\
\hline Inequality & 1201 & 42.7 & 6.5 & 21.4 & 59.3 \\
\hline Openness & 1239 & 72.3 & 35.9 & 0 & 211.3 \\
\hline FDI & 1218 & 3.8 & 5.2 & -37.2 & 55.1 \\
\hline LnGDPcapita & 1224 & 7.2 & 1.0 & 4.7 & 9.7 \\
\hline LnGDPcapita & 1224 & 52.9 & 17.7 & 22.4 & 93.8 \\
\hline Technology & 1165 & 10.9 & 14.7 & 0 & 78.2 \\
\hline Remittances & 1165 & 5.9 & 8.5 & 0.0009 & 98.4 \\
\hline Inflation & 1194 & 7.7 & 11.8 & -18.1 & 254.9 \\
\hline GExpenditure & 1128 & 14.4 & 8.7 & 3.5 & 135.8 \\
\hline Corruption & 1059 & 34.1 & 18.8 & 1.1 & 84.8 \\
\hline
\end{tabular}

\section{Result and Discussion}

\subsection{Full panel regression}

In the first quantitative section, estimation for the total sample (with 59 countries) is conducted. There are three types of the regressive model will be estimated. Each result will be compared with others to furtherly explore the effect of economic integration on income inequality in developing countries. Besides, the estimated process is done with both fixed-effects (FEM) and random-effects (REM) models. The Hausman test will help to decide which result is the better one. However, the Hausman testing results imply that FEM is more appropriate because the chi-square values have Prob (F $=0.00)<0.05$ in all tests, therefore, there are only FEM results will be presented in the below table.

Our estimated results show the Kuznets U-inverted between income and inequality is confirmed because of the positive and significant impact of LnGDPcapita and the negative and significant impact of LnGDPcapita ${ }^{2}$. Besides, FDI and Inflation variables have a positive and significant impact on inequality. On the other hand, Openness and Technology variables have a negative and significant effect on inequality. 
Table 2: The full-panel estimated result

\begin{tabular}{|l|c|c|c|}
\hline \multicolumn{4}{|c|}{ The dependent variable is Inequality } \\
\hline Independent variables & Model 1 & Model 2 & Model 3 \\
\hline FDI & $0.047^{* * *}$ & $0.039^{* * *}$ & $0.045^{* * *}$ \\
\hline Openness & $-0.007^{* * *}$ & $-0.008^{* * *}$ & $-0.071^{* * *}$ \\
\hline LnGDPcapita & & $6.114^{* * *}$ & $2.137^{*}$ \\
\hline LnGDPcapita & & $-0.472^{* * *}$ & $-0.144^{*}$ \\
\hline Technology & & & $-0.045^{* * *}$ \\
\hline Remittances & & & -0.026 \\
\hline Inflation & & & $0.017^{* *}$ \\
\hline GExpenditure & & & -0.003 \\
\hline Corruption & & & 0.011 \\
\hline Constant & $43.17^{* * *}$ & $24.25 * * *$ & $35.92^{* * *}$ \\
\hline R-Square & 0.2050 & 0.1270 & 0.1909 \\
\hline Obs & 1186 & 864 & 864 \\
\hline Countries & 59 & 59 & 59 \\
\hline
\end{tabular}

Note:***,*** denotes significant at $1 \%, 5 \%$ and $10 \%$

The most important points are the sign of economic integration variables including FDI and Openness. First, FDI has a positive and significant effect on inequality in all three models. In fact, FDI brings more advanced technologies (Nguyen, Le, \& Pham, 2017), leading to a higher demand for more skilled workforces, need more professional management teams. Attracting a high number of highly skilled workers might reduce the need for low-skilled workers and reduce the income of low-skilled workers as well, however, contribute to the increase of inequality. Our result is in-lined with some previous studies, such as Alderson and Nielser (2002), Heshmati (2003) or Daumal (2013). Second, the Openness variable has reduced income inequality in the case of developing countries. When international trade between countries rises, many companies have a demand for lowskilled people in labour forces, which leads to improve the income of low-skilled labourers and reduce inequality. Our result is consistent with some previous results (eg., Tian et al., 2008; Daumal, 2013; Baek \& Shi, 2016; Ametoglo \& Ping, 2016).

The GDPcapita variable has a positive and significant impact on inequality, besides, the LnGDPcapita $^{2}$ variable has a negative and significant effect on reducing income inequality. Our finding represents a Kuznets inverted-U curve (Illustrating the basic elements of the Kuznets hypothesis with income per capita plotted on the horizontal axis and Economic inequality on the vertical axis). In our study, the quantitative result shows that income inequality increases first and then decreases after peaking as per capita income increases during the economic development process. Our result is supported by a number of previous studies, for example, Mihaylova (2015). However, in some low-income countries, when income increases, the income gap between the richest and the poorest widens, respectively. This situation can lead to an increase in the inequality between income groups in society.

Besides, we find that the Inflation variable positively and significantly affects inequality. This evidence is consistent with previous studies by Lee (2010) or Mihaylova (2015). This result can be explained that people having low-income levels are most affected by inflation due to the increase in prices of essential goods, while those with high-income 
are not. So inflation can lead to an increase in inequality level. The Technology variable has a negative and significant impact on inequality. It is mean that a higher population in a specific country using the internet, the more stable their income will be, which would positively affect inequality. Our finding is in accordance with the research of Heshmati (2003), Zhou et al. (2011) or Baek and Shi (2016).

However, the estimated results also show that the statistical insignificance of the effect of other variables on inequality including Government expenditure, Remittances, and Corruption. Because the coefficients are not statistically significant, so we can not conclude about the real direction of these variables on inequality in this case. In fact, there are some different indicators among regions that can lead to this problem. In order to deeply analysis the relationship between economic integration and inequality, there are some smaller samples that will be used to explore the study topic with the specificity of the regions.

\subsection{Regression results for Continental sub-samples}

For deep analysis, in this section, there are three quantitative results regarding three continental samples including Asia (22 countries), African (22 countries) and LatinAmerica (15 countries). Besides, there are three models that are estimated in each continental region as the previous section. The regression results show that there are some differences between the three continental samples of developing countries.

First, we need to focus on economic integration variables. Our results show that FDI increases inequality and is significant for all estimated models. It can be concluded that there is an increase in inequality level when FDI comes to developing countries in Asia, Africa, and Latin-America. There is a new finding that the impact of FDI on inequality in the LatinAmerica is quite higher than in Asia and Africa. Besides, we also find that the Openness variable had a negative and significant impact on inequality in developing countries in Asia and Latin-America. However, this effect is opposite in Africa, the increase in trade openness in African developing countries can lead to higher inequality in these countries.

Second, the Kuznets inverted-U curve between income - inequality nexus is only confirmed in the case of Asia and Africa, while it is not apparent in Latin-America. Unlike other regions, the income-inequality issue in the Latin-America has been a complex issue for a long time.

Table 3: The estimated results of the continental sub-samples

\begin{tabular}{|l|c|c|c|c|c|c|c|c|c|}
\hline \multicolumn{9}{|c|}{ The dependent variable is Inequality } \\
\hline \multirow{2}{*}{ Independent variables } & \multicolumn{3}{|c|}{ Model 1 } & \multicolumn{3}{c|}{ Model 2} & \multicolumn{3}{c|}{ Model 3} \\
\cline { 2 - 10 } & Asia & Africa & Latin-America & Asia & Africa & Latin-America & Asia & Africa & Latin-America \\
\hline FDI & $0.04^{* * *}$ & $0.02^{* * *}$ & $0.13^{* * *}$ & $0.03^{* * *}$ & $0.02^{* * *}$ & $0.2^{* * *}$ & $0.04^{* * *}$ & $0.02^{* * *}$ & $0.12^{* * *}$ \\
\hline Openness & $-0.01^{* * *}$ & $0.01^{* * *}$ & $-0.03^{* * *}$ & $-0.01^{* * *}$ & $0.01^{* * *}$ & $-0.06^{* * *}$ & $-0.01^{* * *}$ & $0.01^{* *}$ & $-0.05^{* * *}$ \\
\hline LnGDPcapita & & & & $8.91^{* * *}$ & $1.86^{* *}$ & $-13.1^{* *}$ & $13.0^{* * *}$ & 1.90 & $-26.0^{* * *}$ \\
\hline LnGDPcapita & & & & $-0.65^{* * *}$ & $-0.13^{* *}$ & $0.56^{* *}$ & $-0.93^{* * *}$ & -0.13 & $1.52^{* * *}$ \\
\hline Technology & & & & & & & -0.01 & -0.01 & $-0.08^{* * *}$ \\
\hline Remittances & & & & & & & $-0.10^{* * *}$ & -0.02 & $-0.08^{* * *}$ \\
\hline Inflation & & & & & & & -0.01 & 0.01 & -0.01 \\
\hline GExpenditure & & & & & & & 0.01 & -0.01 & -0.05 \\
\hline Corruption & & & & & & & $0.03^{* * *}$ & $0.01^{* *}$ & $-0.05^{* * *}$ \\
\hline Constant & $39.2^{* * *}$ & $42.9^{* * *}$ & $48.6^{* * *}$ & $9.41^{* * *}$ & $36.5^{* * *}$ & $119^{* * *}$ & $8.47^{* * *}$ & $35.5^{* * *}$ & $164^{* * *}$ \\
\hline R-Square & 0.0419 & 0.2075 & 0.0717 & 0.2000 & 0.1402 & 0.6624 & 0.1909 & 0.1909 & 0.7210 \\
\hline Obs & 429 & 445 & 309 & 428 & 445 & 309 & 328 & 292 & 244 \\
\hline Countries & 22 & 22 & 15 & 22 & 22 & 15 & 22 & 22 & 15 \\
\hline
\end{tabular}

Note:*****,* denotes significant at $1 \%, 5 \%$ and $10 \%$. 
Third, the Technology variable is found to have a negative and significant impact on the Latin-America region, while this impact is not significant in Asia and Africa. However, we can conclude that the more people in a country using the internet, the less in the inequality level. Remittance inflows negatively and significantly affect income inequality meaning this variable can help to reduce inequality in Asian and Latin-American developing countries. The impact of the Remittances variable in Asia is stronger than the Latin-American region, this evidence may be Asia is the most remittance inflows in the developing world (Tung et al., 2015; Tung, 2018b; Tung, 2018c). Besides, it can not be concluded in the case of the African region because the coefficient is not significant.

However, there is a new finding regarding the Corruption variable. Our result shows that an increase in corruption control can lead to significantly rising inequality levels in Asia and Africa region. On the other hand, in the Latin-America region, an increase in corruption control can make inequality reduce. This difference is explained in the study of Beak and Shi (2015), which concluded that a higher the index meaning the less corrupt the political governance, finally, the inequality would be decreasing. However, we can not conclude about the impact of Inflation and Government expenditure on inequality in the case of continental sub-samples because all of the coefficients are not significant.

\section{Conclusions}

For recent decades, economic integration plays an important role in the increase of per capita income in many countries worldwide. However, the real effect of economic integration on income inequality in developing countries remains much controversial. Our paper focuses on investigating the impact of economic integration on inequality regarding a statistical sample of 59 countries in 1996-2016. In order to have a deeper analysis, we continue to divide this database was into three continental sub-groups including in Asia, Africa, and Latin-America. Our research results show that Openness has a significant effect on reducing inequality in most countries, while FDI increases inequality in these countries. FDI has a positive and significant impact on inequality in all estimated results. Besides, the Kuznets inverted-U curve is confirmed in most of the estimated results (exclude the Latin-America sample). We find that the Technology variable has a negative and significant effect on inequality in the total sample and the Latin-America region. Furthermore, the Inflation variable has only a significant impact on increasing inequality in the total sample. The Corruption variable has a positive and significant effect on inequality in Asia and Africa, however, a negative and significan impact in the Latin-America region. Finally, we find that the increase of Remittance inflows leads to a decrease in inequality level in Asia and Latin-America.

There are some policy implications coming from our research results. Inequality is becoming a popular problem that needs governments to build a comprehensive social welfare system and increasing subsidies for poor or vulnerable people to ensure the majority of people have access to good socioeconomic policies to reduce inequality. On the other hand, income tax policy is also very important to regulate the income of the high-income and the rich in society to the weaker people. Thus, tax policy is an effective tool if used appropriately to reduce inequality and create social justice and reduce the gap 
between rich and poor. In order to expand the positive effect of FDI, governments should support low-skill workers in finding jobs in foreign companies as well as and stabilizing their lives before economic fluctuations. Besides, trade openness needs to continue supported by public policies to ensure a large of people can receive the positive of international trade.

Furthermore, investments in infrastructure are aimed at socio-economic development, improving labor productivity, reducing commodity costs, and increasing the competitiveness of the economy. These solutions help goods and services can be competitive in all market areas. It is necessary to support capital for startups, especially those with low resources, to have preferential loans, creating equal access to finance for low-income groups and small individual business households. The government needs to create a stable socio-economic environment and a stable and safe legal framework for production and business activities and create conditions to help all economic sectors, facilitating social justice for all people.

\section{References}

Alderson, A.S., \& Nielsen, F., (2002). Globalization and the great U-turn: Income inequality trends in 16 OECD countries, American Journal of Sociology, 107(5), pp.1244-1299.

Ametoglo, M., \& Ping, G., (2016). Regional economic integration and income inequality in Latin America: the case of the Andean Community of Nations. Journal of Economics and Sustainable Development, 7(14), 176-185.

Baek, I. and Shi, Q., (2016). Impact of Economic Globalization on Income Inequality: Developed Economies vs Emerging Economies. Global Economy Journal, 16(1), pp.49-61.

Bergh, A. \& Nilsson, T. (2010). Do liberalization and globalization increase income inequality? European Journal of Political Economy, 26(4), 488-505.

Daumal, M. (2013). The impact of trade openness on regional inequality: the cases of India and Brazil, The International Trade Journal, 27(3), 243-280.

Dollar, D. \& Kraay, A. (2004) Trade, growth and poverty, The Economic Journal, 114 (493), F22-F49.

Ezcurra, R., \& Rodríguez-Pose, A. (2014). Trade Openness and Spatial Inequality in Emerging Countries, Spatial Economic Analysis, 9(2), 162-182.

Franco, C., \& Gerussi, E. (2013), Trade, foreign direct investments (FDI) and income inequality: Empirical evidence from transition countries, The Journal of International Trade \& Economic Development, 22(8), 1131-1160.

Goldberg, P. K., \& Pavcnik, N. (2007). Distributional Effects of Globalization in Developing Countries. Journal of Economic Literature, 41(1), 39-82.

Heshmati, A. (2003). The relationship between income inequality and globalization. Working-paper, The United Nations University, Helsinki, Finland.

Hoekman, B., Aaditya, M., \& Philip, E. (2002). Development, Trade and the WTO: a handbook. The World Bank, Washington, D.C, USA.

Inekwe, J. N., Jin, Y. and Valenzuela, M. R. (2018). A new approach to financial integration and market income inequality. Emerging Markets Review, 37, 134-147.

Iyoha, M. A. (2005). Enhancing Africa's Trade: From Marginalization to an Export-LedApproach to Development, Economic Research Working Paper Series (77), African Development Bank.

Jiang, Y. (2016). Trade integration and regional inequality: a theoretical framework with empirical implications for China, Journal of Chinese Economic and Business Studies, 14(4), 365-384.

Kuznets, S. (1955). Economic Growth and Income Inequality. American Economic Review, 45 (1), 01-28.

Le, H. T., Booth, A. L. (2014). Inequality in Vietnamese Urban-Rural Living Standards, 1993-2006. Review of Income and Wealth, 60(4), 862-886.

Lee, J-E. (2010) Inequality in the globalizing Asia. Applied Economics, 42(23), 2975-2984. 
Markusen, J. R., \& Venables, A. J. (1999). Foreign direct investment as a catalyst for industrial development. European Economic Review, 43(2), 335-356.

Meniago, C., \& Asongu, S. A., (2018). Revisiting the finance-inequality nexus in a panel of African countries. Research in International Business and Finance, 46, pp.399-419.

Mihaylova, S., (2015). Foreign direct investment and income inequality in Central and Eastern Europe. Theoretical \& Applied Economics, 22(2), 23-42.

Nascia, L., \& Pianta, M. (2009). Forces of Inequality? the Impact of Technology and Globalization. Intereconomics, 44, 332.

Nguyen, T. N., Le, T. T, \& Pham, T. Q. N. (2017). The impact of Technology spillover from Foreign direct investment on Economic growth: Evidence in Vietnam. The Proceeding of the 11 th International Days of Statistics and Economics, 42-51, Prague, Czech Republic.

Park, I., \& Park, S. (2009). Reform Creating Regional Trade Agreements and Foreign Direct Investment: Applications for East Asia, Pacific Economic Review, 13(5), 550-566.

Tian, X., Wang, B., \& Dayanandan, A. (2008). The Impact of Economic Globalization on Income Distribution: Empirical Evidence in China. Economics Bulletin, 4(35), 1-8.

Tung, L. T., Ly, P. T. M., Nhu, P. T. Q., Thanh, P. T., Anh, L. T., \& Phung, T. T. P. (2015). The Impact of Remittance Inflows on Inflation: Evidence in Asian and The Pacific Developing Countries. Journal of Applied Economic Sciences, 10(7), 1076-1084.

Tung, L. T. (2018a). The effect of fiscal deficit on economic growth in an emerging economy: Evidence from Vietnam. Journal of International Studies, 11(3), 191-203.

Tung, L. T. (2018b). The Impact of Remittances on domestic investment in developing countries: Fresh evidence from the Asia-pacific region. Organizations and Markets in Emerging economies, 9(2), 193-211.

Tung, L. T. (2018c). Impact of remittance inflows on trade balance in developing countries. Economics and Sociology, 11(4), 80-95.

Tung, L. T. (2019). Does Foreign Direct Investment Really Support Private Investment in an Emerging Economy? An Empirical Evidence in Vietnam. Montenegrin Journal of Economics, 15(1), 7-20.

Tung, L. T., Thang, P. N. (2020). Impact of FDI on Private Investment in the Asian and African Developing Countries: A Panel-Data Approach. Journal of Asian Finance, Economics and Business, 7(3), 295-302.

Wei, S-J., \& Wu, Y. (2001). Globalization and Inequality: Evidence from Within China, NBER Working Papers 8611, National Bureau of Economic Research, Inc.

Wong, M. Y. H. (2016). Globalization, spending and income inequality in Asia-Pacific. Journal of Comparative Asian Development, 15(1), 1-18.

World Bank. (2019). World Development Indicators online database. Washington, DC. Available at: http://data.worldbank.org/indicator

Wu, J-Y., \& Hsu, C-C. (2012). Foreign direct investment and income inequality: Does the relationship vary with absorptive capacity?. Economic Modelling, 29(6), 2183-2189.

Zhou, L., Biswas, B., Bowles, T., \& Saunders, P. J. (2011). Impact of globalization on income distribution inequality in 60 countries. Global Economy Journal, 11(1), 1850216. 